\title{
Assessment of Inflammatory Response on Pyrogenic Induction by In vitro and In vivo Methods
}

\author{
Prajitha Nadukkandy 1,\#, Megha Kizhakkepurakkal Balachandran ${ }^{1, \# \text {, }}$ \\ Mohanan Parayanthala Valappil 1 ,* (D)
}

1 Toxicology Division, Biomedical Technology Wing, Sree Chitra Tirunal Institute for Medical Sciences and Technology (Govt. of India), Poojapura, Trivandrum 695 012, Kerala, India

\# Equal authorship and equally contributed;

* Correspondence: mohanpv10@gmail.com, mohanpv@sctimst.ac.in;

Scopus Author ID 7006010446

Received: 13.09.2021; Revised: 1.11.2021; Accepted: 4.11.2021; Published: 28.11.2021

\begin{abstract}
The incidence of pyrogenic contaminations creates a paramount safety concern in the field of biotherapeutics, as it compromises the normal well-being of an individual. After exposure to pyrogenic agents, the febrile response can create a severe reaction from shock and further complications leading to death. So it is imperative that the medical aids, as well as the parenteral drugs, must be pyrogen-free. The possible reliability of continuous supply of healthy human blood can be overcome by implementing a novel approach by pooling the blood samples for checking the pyrogenicity. In this study, an indigenously developed sandwich ELISA method to quantify pro-inflammatory cytokine (IL$1 \beta)$ activated after pyrogenic exposure was used. The study unraveled the possibility of using the human pooled blood system to detect the endogenous pyrogen (IL- $\beta$ ) after exposure to endotoxins from Grampositive and negative bacteria and chemical toxicants such as phytohemagglutinin (PHA) and 2,4,6trinitrophenol (TNP). The results indicate that upon exposure to the high concentration of endotoxin such as LPS $(5 \mathrm{EU} / \mathrm{ml})$ and LTA $(1 \mu \mathrm{g} / \mathrm{ml})$, the maximum release of IL-1 $\beta$ was observed within $2 \mathrm{~h}$ of post-stimulation. The stimulation with chemical toxicants PHA and TNP triggered a sudden release of IL- $1 \beta$ within $2 \mathrm{~h}$ in both cases after $30 \mu \mathrm{g} / \mathrm{ml}$ treatment. The study conveys a better platform for providing a continuous supply of healthy human blood, thus minimizing personal variations for the detection of IL-1 $\beta$ for evaluating in vitro pyrogenic response. It also depicts understanding the possible underlying mechanism of the pyrogenic response level of inflammatory cytokines and the possible rise in biochemical parameters leading to complications that affect the normal homeostasis by lipopolysaccharide-induced in rabbits.
\end{abstract}

Keywords: pyrogens; alternatives; ELISA; endotoxins; interleukin $1 \beta$.

(C) 2021 by the authors. This article is an open-access article distributed under the terms and conditions of the Creative Commons Attribution (CC BY) license (https://creativecommons.org/licenses/by/4.0/).

\section{Introduction}

The rapid development of biomedical research enlightens the need for detecting various classes of bacterial and non-bacterial contaminations based on their structural and other unique characteristics that they do not share with the human body. , The presence of micro-organisms or their structural components in biomedical products intended to use in the health care system may result in the activation of the immune system, especially the phagocytic cells, monocytes, and macrophages. These phagocytic cells interact with highly conserved structures of microorganisms like lipopolysaccharides and lipoteichoic acid, respectively, from Gram-negative and Gram-positive bacteria. Lipopolysaccharides (LPS) are also known as endotoxin, the key activator of fever and febrile reaction in humans [1]. Any substance that can induce fever and 
febrile reaction are collectively called pyrogens [2]. The immune cells principally react with exogenous pyrogens and release endogenous mediators known as pyrogenic cytokines. Cytokines, including Interleukin-1beta (IL-1 $\beta$ ), Interleukin-6 (IL-6), and Tumor necrosis factor-alpha (TNF- $\alpha$ ), are the well-established pyrogenic cytokines that signals pyrogenic stimuli to the preoptic area of the hypothalamus where the thermoregulatory mechanism maintain body temperature in a physiological range of $36.5-37.5^{\circ} \mathrm{C}$ [3]. Unintentional contamination of pharmaceuticals, injectables, recombinant proteins, implants, and medical devices with various classes of pyrogens may lead to unwanted complications associated with pyrogenic response. Uncontrolled fever and febrile reactions may be fatal, or it may lead to septic shock [4-6]. Therefore, detecting pyrogenic contamination in medical products is crucial to ensure their quality and safety before human use.

Over the past years, from 1940's the pyrogens were detected mainly by consuming rabbits as test animal and was widely accepted as rabbit pyrogen test (RPT). The rise of rectal temperature of rabbits in response to test material is considered pyrogenic. After 1970's an in vitro alternate system termed Limulus Amebocyte Lysate (LAL) test was developed, which uses hemolymph collected from horseshoe crab to detect bacterial endotoxin [7]. Even though LAL test is very sensitive for endotoxin detection, it is not suitable for the detection of other classes of pyrogens, including Lipoteichoic acid (LTA). It was noted that fungal, viral, biological, and chemical agents also induce a pyrogenic response in humans. After a long period of research efforts, an in vitro alternative for RPT was developed and was included in European pharmacopeia in 2010. This test is called the monocyte activation test (MAT), which permits the detection of pyrogenic contaminations using monocyte, monocyte-macrophage cell lines, or using whole human blood [8]. MAT exploits the pyrogenic response in the in vitro system exactly like a human, where monocytes and macrophages present in the whole blood interact with exogenous pyrogens and release pyrogenic cytokines. The concentration of pyrogenic cytokines released from these in vitro systems directs the possible pyrogenic contamination in the test sample. MAT was suitable for detecting any type of pyrogens present in the test sample, either liquid or solid.

The pyrogenic cytokines present in the cell culture supernatant or which are released from blood cells are easily detectable using Enzyme-Linked ImmunoSorbent assay (ELISA). Whole blood collected from healthy human volunteers mimics the in vivo environment to monocytes and macrophages in their natural environment. So the pyrogenic response offered by immune cells will be more or less comparable with the natural mechanism. However, the distribution of lymphocytes from individual donors may differ from each other. To minimize inter-individual variation in cytokine release from immune cells, the present study collected whole blood from individuals and pooled it together to use as a test system. Pooled blood was stimulated with bacterial and non-bacterial pyrogens include LPS, LTA, Phytohemagglutinin (PHA), and 2, 4, 6-trinitrophenol (TNP) (figure 1).

PHA is a plant lectin from red kidney bean, which is a well-known mitogen [9] where TNP is a chemical pyrogen. Pooled human blood stimulated with these pyrogen released pyrogenic cytokines was estimated using an indigenously developed ELISA kit from the Division of Toxicology, SCTIMST. Since IL-1 $\beta$ is the well-established and suitable representative of endogenous pyrogen [10-12], the present study selected IL-1 $\beta$ as the target cytokine for pyrogen detection. Rabbits are the most suitable animal to study pyrogenic responses. The present study also focused on the pyrogenic response of rabbits to bacterial LPS 
and associated inflammatory reactions. Since cytokines are the potent inflammatory mediators, their release and expression of cytokines from rabbit blood lymphocytes were evaluated.

Lipopolysacharide

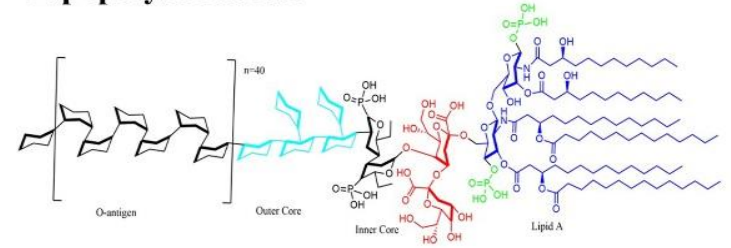

Lipoteichoic acid

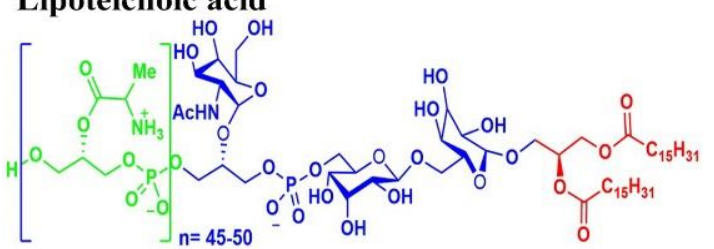

Phytohemagglutinin

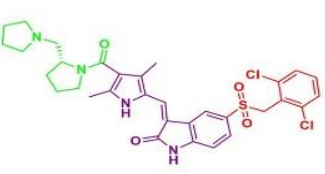

2,4,6-tinirophenol

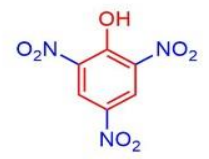

Figure 1. Structure of LPS, LTA, PHA, and TNP.

\section{Materials and Methods}

Pyrogen-free 0.9\% saline (Bendtt, India), Sterile filtered pyrogen-free RPMI1640 media (Himedia, India), Endotoxin standards from E. coli strain 055: B5 lipopolysaccharide (Sigma Aldrich), Lipoteichoic acid from Bacillus subtilis (Sigma Aldrich), Reagent-grade 2,4,6-trinitrophenol (Sigma Aldrich), Phytohaemagglutinin lectin from Phaseolus vulgaris (Sigma Aldrich), Sterile pyrogen-free 96- well flat-bottom microplates (NuncMaxisorp), Albumin fraction V from bovine serum (BSA) for biochemistry (Merck, Germany), TMB plus liquid 1 component substrate (Amersco, India), Heparin extra pure (Himedia, India), RNeasy Mini Kit (Qiagen, Germany), PrimeScript 1st strand cDNA synthesis kit and PCR master mix were purchased from Takara Bio (Japan), Biochemistry reagents for blood analysis were purchased from Erbamannhiem (Germany). Reagents for hematological analysis were procured from Horiba (Japan). The glassware used for the in vitro pyrogen assay was depyrogenized at $250^{\circ} \mathrm{C}$ for $30 \mathrm{~min}$ before the experiment, and the reagents and materials are of pyrogen-free grade.

\subsection{Collection of whole human blood.}

Healthy human volunteers who did not suffer from any disease, either taken any medication, or were afflicted with physical injury for at least two weeks were selected for the study. Informed consent was obtained from the volunteers for collecting blood for the study (SCT/IEC/1366/April-2019, IEC Regn No: ECR/189/Inst/KL/2013/RR-16). Fresh venous blood was drawn from individuals and transferred into heparinized as well as plain tubes. Individual blood samples were pooled within $15 \mathrm{~min}$ of collection. Blood samples were used to induce cytokine production within $1 \mathrm{~h}$ of blood collection.

\subsection{Hematological and biochemical analysis.}

The collected individual and pooled blood were checked for parameters such as Platelet count, WBC count, RBC count, and Hemoglobin within an hour of blood collection. The complete blood cell count was performed using an automated hematology analyzer (SYSMEX K4500). The serum separated from an individual as well as pooled blood was analyzed for biochemical parameters such as Glucose, Cholesterol, Triglycerides, Alanine transaminase 
(ALT), Aspartate transaminase (AST), Alkaline phosphatase (ALP), Total Bilirubin, Total Protein, Albumin, and Creatinine using Biochemistry analyzer: Erba Mannheim XL300.

\subsection{Induction of cytokines.}

Pooled human whole blood was used to induce a pyrogenic response. The reaction mixture was taken in a $1.5 \mathrm{ml}$ pyrogen-free microcentrifuge tube. LPS from Escherichia coli (1 and 5EU/ml), LTA from Bacillus subtilis $(0.1$ and $1 \mu \mathrm{g} / \mathrm{ml})$, PHA from Phaseolus vulgaris (15 and $30 \mu \mathrm{g} / \mathrm{ml})$ and 2, 4, 6- trinitrophenol (TNP) $(15$ and $30 \mu \mathrm{g} / \mathrm{ml})$ were used as stimulators of pyrogenic response. The experimental details are described in Table 1.

Table 1. Induction of IL-1 $\beta$ from pooled human blood.

\begin{tabular}{l|c|c} 
& Control & Test \\
\hline Heparinized Blood & $250 \mu \mathrm{l}$ & $250 \mu \mathrm{l}$ \\
\hline RPMI 1640 media & $250 \mu \mathrm{l}$ & $250 \mu \mathrm{l}$ \\
\hline Pyrogen & - & $10 \mu \mathrm{l}$ \\
\hline Physiological saline & $500 \mu \mathrm{l}$ & $490 \mu \mathrm{l}$ \\
\hline Incubate the reaction mixture at $37^{\circ} \mathrm{C} / 5 \% \mathrm{CO} 2$ for 0 to $8 \mathrm{~h}$. \\
Collect supernatant in every $2 \mathrm{~h}$ intervals/separate by centrifugation at $500 \mathrm{~g}$ for 2 \\
min at $4{ }^{\circ} \mathrm{C}$. Store supernatants at $-20^{\circ} \mathrm{C}$ until analysis.
\end{tabular}

\subsection{Measurement of interleukin-1 $(I L-1 \beta)$.}

An indigenously developed ELISA kit was used for the estimation of IL-1 $\beta$ released from pooled whole blood. Briefly, the ELISA plate was prepared by coating affinity purified anti-human IL-1 $\beta$ antibodies in a sterile 96 well microplate. $50 \mu 1$ of anti-human IL- $1 \beta$ in $50 \mathrm{mM}$ carbonate bicarbonate buffer ( $\mathrm{pH}$ 9.6) was added to each well of a 96 well plate and incubated overnight at $4^{\circ} \mathrm{C}$. The unbound surface was blocked with blocking solution $(137 \mathrm{mM} \mathrm{NaCl}$, $2.7 \mathrm{mM} \mathrm{KCl}, 10 \mathrm{mM} \mathrm{Na} 2 \mathrm{HPO}_{4}, 2 \mathrm{mM} \mathrm{KH}_{2} \mathrm{PO}_{4}, 1 \% \mathrm{BSA}, \mathrm{pH}$ 7.2) for $1 \mathrm{~h}$ at room temperature. After washing with washing buffer $\left(137 \mathrm{mM} \mathrm{NaCl}, 2.7 \mathrm{mMKCl}, 10 \mathrm{mM} \mathrm{Na}_{2} \mathrm{HPO}_{4}, 2 \mathrm{mM}\right.$ $\mathrm{KH}_{2} \mathrm{PO}_{4}, \mathrm{pH}$ 7.2), $50 \mu 1$ of the diluted serum samples (1:20 in blocking solution) were incubated for $2 \mathrm{~h}$ at room temperature. The wells were washed again and incubated with $100 \mu \mathrm{l}$ of diluted anti-IL1 $\beta$-HRP conjugate for $2 \mathrm{~h}$ at room temperature. After washing, the wells were incubated with TMB substrate for $30 \mathrm{~min}$ in the dark. $100 \mu \mathrm{l}$ of $1 \mathrm{M} \mathrm{H}_{2} \mathrm{SO}_{4}$ was added to stop the reaction, and absorbance reading was taken using an ELISA plate reader (ASYS Expert plus) at $450 \mathrm{~nm}$.

\subsection{Detection of pyrogenicity using rabbits.}

Study of in vivo immune response after LPS administration was carried out using New Zealand white rabbits. New Zealand white rabbits were procured from the Division of Laboratory Animal Sciences, Biomedical Technology Wing, Sree Chitra Tirunal Institute for Medical Sciences and Technology (Govt. of India), Trivandrum. All the animals were handled humanely, without causing any pain or distress, and with due care for their welfare. The care and management of the animals were carried out in compliance with the Committee for Control and Supervision of Experiments on Animals (CPCSEA). All the experiments were carried out after getting approval from the Institute Animal Ethics Committee (IAEC). Animal experiments conformed to the guidelines of IAEC regulations approved by the CPCSEA, Govt. of India. Clearance was obtained from IAEC for carrying out the study. IAEC approval No: SCT/IAEC-384/NOVEMBER/2020/107. 


\subsubsection{Exposure of endotoxins to rabbits.}

Healthy New Zealand white rabbits of either sex weighing 2-3 Kg were used for the study. Rabbits before administration of LPS were considered as the control group. Animals were conditioned for 7 days, and rectal temperature was recorded every $30 \mathrm{~min}$ for $3 \mathrm{~h}$. Before conditioning, venous blood was withdrawn from the marginal ear vein for biochemical, hematological, and immunological analysis. The rectal temperature of all three animals was recorded 30 min before the administration of endotoxin. Animals received i.v. administration of LPS in saline $(10 \mathrm{ml} / \mathrm{kg}$ body weight) was the test group. Test animals were observed for temperature fluctuation at every $30 \mathrm{~min}$ interval for $180 \mathrm{~min}$ after LPS administration. After $3 \mathrm{~h}$, blood was taken from each animal for biochemical, hematological, and immunological analysis.

\subsubsection{Measurement of pyrogenicity.}

The pyrogenic potential of LPS through intravenous administration was assessed as per USPA1/NF36, 2018. Pyrogen-free syringes, needles, and glassware were used for the study. LPS prepared in normal physiological saline was warmed at $25^{\circ} \mathrm{C}$ for 30 min before i.v. administration. All rabbits were housed in an area of uniform temperature, and their rectal temperature was taken using a thermometer. Rabbit, whose temperature does not vary by more than $1^{\circ} \mathrm{C}$ from each other, was selected for the study. Rectal temperature is taken $30 \mathrm{~min}$ before the injection serves as control temperature. The ear vein of rabbits was disinfected with $70 \%$ alcohol, and LPS (1EU/kg) containing solution was administrated into the ear vein of each of three rabbits at a dose of $10 \mathrm{ml} / \mathrm{kg}$ body weight within $10 \mathrm{~min}$. The rectal temperature of each rabbit was recorded at every $30 \mathrm{~min}$ interval for a period of $3 \mathrm{~h}$ after the injection. Rabbit shows an individual rise of $0.5^{\circ} \mathrm{C}$ or more above its respective control temperature was considered as positive.

\subsubsection{Evaluation of hematological and biochemical analysis.}

Fresh venous blood was collected from each animal in heparinized blood collection tubes and was subjected to hematology analysis within an hour of collection. Hematology blood parameters, including hemoglobin (HGB) level, hematocrit (HCT), red blood cell (RBC), white blood cell (WBC), and platelet (PLT) count, were analyzed using an automated hematology analyzer, Horiba Vet ABC (Japan). For biochemical analysis, venous blood from each animal was collected in plain blood collection tubes and was allowed to clot at room temperature. The serum was separated by centrifugation at $3500 \mathrm{rpm}$ for $15 \mathrm{~min}$. Routine biochemistry analysis including blood sugar, total protein, albumin, creatinine, bilirubin, cholesterol, alkaline phosphatase (ALP), aspartate aminotransferase (SGOT), alanine transaminase (SGPT), etc., were analyzed by an automated biochemistry analyzer, Erba Mannheim XL300 (Germany).

\subsubsection{Measurement of serum cytokine level.}

The major inflammatory cytokine released from immune cells of rabbits before and after i.v. administration of LPS was assessed using commercially available ELISA kits. Serum collected from clotted blood samples were analyzed for cytokines IL-1 $\beta$, IL-8, and TNF- $\alpha$ as per the manufacturer's instruction. 


\subsubsection{Isolation of peripheral blood lymphocytes.}

Venous blood collected from the marginal ear vein of the animal was transferred into a heparinized tube to prevent clotting. Blood was diluted with an equal volume of PBS (pH 7.4) and mixed by tilting. Diluted blood was layered over with Histopaque 1077 solution and centrifuged at $900 \mathrm{xg}$ for $30 \mathrm{~min}$ at room temperature to achieve density gradient separation of blood components. The supernatant containing plasma and platelets was removed by aspiration. The buffy coat layer containing mononuclear cells in the interface between the plasma and packed RBCs were aspirated carefully and transferred into a fresh centrifuge tube. Collected PBMCs were washed twice with an excess volume of sterile PBS and resuspended in RPMI-1640 medium. Cell viability was assessed by staining with trypan blue dye.

\subsubsection{Cytokine gene expression from rabbit PBMC-QRTPCR.}

Total RNA was isolated PBMC exposed to LPS using RNeasy Mini Kit-QIAGEN, according to the manufacturer's instruction. RNA concentration was estimated by measuring the absorbance at $260 \mathrm{~nm}$ using a Biophotometer (Eppendorf). RNA isolated from control and test samples were kept frozen at $-20^{\circ} \mathrm{C}$ until use. First-strand complementary DNA (cDNA) was reverse transcribed from 200ng of total RNA from the samples using the reverse transcriptase core kit, according to the manufacturer's instructions. cDNA prepared from control and test samples were stored at $-20^{\circ} \mathrm{C}$. The qRT-PCR reaction was performed in a BioRad instrument. Expression of IL-1 $\beta, \mathrm{NF \kappa B}$, and IL-8 was analyzed. Polymerase chain reactions were performed using the following amplification program: initial denaturation at $95^{\circ} \mathrm{C}$ for $1 \mathrm{~min}, 35$ cycles of $3 \mathrm{~s}$ denaturation at $95^{\circ} \mathrm{C}, 30 \mathrm{~s}$ annealing at $51-62^{\circ} \mathrm{C}$, and finally $15 \mathrm{~s}$ extensions at $72^{\circ} \mathrm{C}$. The program was terminated with $10 \mathrm{~min}$ at $72^{\circ} \mathrm{C}$. Reference gene $\beta$-actin (ACTB) was used for normalizing the gene expression data. Amplification of genes and data analysis were done by using the system software. Melting curve analysis was done to monitor the specificity of the amplified product. The primer sequence for all cytokine genes is given in Table 2.

Table 2. Primers for rabbit cytokine genes.

\begin{tabular}{l|l|l} 
S.No & Genes & Primer Sequence \\
\hline 1 & IL-1 $\beta$ & $\begin{array}{l}\text { FP:5'-TTGAAGAAGAACCCGTCCTCTG-3' } \\
\text { RP:5'-CTCATACGTGCCAGACAACACC-3' }\end{array}$ \\
\hline 2 & NFkB & $\begin{array}{l}\text { FP:5'-CAAGAAGTCCACAAACAC-3' } \\
\text { RP:5'-ACCGATATGTCCTCTTTC-3' }\end{array}$ \\
\hline 3 & IL-8 & $\begin{array}{l}\text { FP: 5'-GCTAAGAATACTGGAATTGT-3' } \\
\text { RP:5'-TAGGATGTTGGCTGATAC-3' }\end{array}$ \\
\hline 4 & GAPDH & FP:5'-TGACGACATCAAGAAGGTGGTG-3' \\
& & RP:5'-GAAGGTGGAGGAGTGGGTGTC-3'
\end{tabular}

\section{Results and Discussion}

The continuous progress in medical research is mainly focused on the safety aspect of therapeutic products, medical devices, implants, and biological materials. Even though the exposure of the medical devices or parenteral drugs may be temporary or permanent, there is a chance of direct or indirect contact of these materials with blood, cells, tissues, and organs. The presence of any of these non-self-substances can evoke a primary immune response mainly driven by monocytes, macrophages, and neutrophils [13]. The accidental contamination of pyrogenic substances in the parenteral drugs, medical devices, tissue-engineered products, and biomaterials can induce severe life-threatening febrile reactions leading to septic shock and even death. Many microbial, organic, and inorganic substances of varying origin and 
composition are present in the environment, capable of inducing severe fever/febrile responses in the living system. The known examples of pyrogens are LPS [14] and LTA [15].

European pharmacopeia recommends three pyrogen assays, namely RPT, LAL, and MAT. All these assays are validated and regulated to test pyrogenic contamination in medical products $[7,13,16]$. Inadequate sensitivity, the requirement of many animals, and species variations are the major drawbacks faced by the conventional pyrogen assay. To overcome these shortcomings, an IVPT method was developed by Hartung and Wendel in 1995 to detect pyrogenic cytokines released from human immune cells in response to bacterial and nonbacterial pyrogens [17]. The concentration-dependent release of IL-1 $\beta$ by the monocytes and tissue macrophages after direct contact with exogenous pyrogenic substances makes it a readout parameter of pyrogenicity [18].

\subsection{Analysis of biochemical and Hematological parameters in human blood.}

The present study pooled human blood from healthy volunteers after checking their routine hematology and biochemical parameters were used to detect IL-1 $\beta$. The major problem of using individual blood samples for IVPT is the unusual reaction of individual donors to different pyrogen stimuli. Pooling of blood samples facilitates easy availability of the required amount of blood for the assay, reduces the inter-individual variation of cytokine release, and maintains the requisite number of healthy leukocytes required to release IL-1 $\beta$. Detection of IL-1 $\beta$ present in the serum separated from pyrogen-induced pooled human blood was performed using indigenously developed ELISA plates [19]. The study evaluated the pyrogenic response of pooled human blood after treating with different concentrations of LPS, LTA, PHA, and TNP. This study also facilitates detection of IL- $\beta$ release after pyrogenic induction concerning time and the concentration of pyrogen required to stimulate pooled blood. It was reported that IL-1 $\beta$ is the most suitable readout parameter for IVPT as it is consistently released in a concentration-dependent manner upon exposure to the same minimal pyrogenic stimulation. Measurement of IL- $1 \beta$ is very much feasible with the ELISA technique [20].

Biochemical parameters such as glucose, cholesterol, triglycerides, ALT, AST, ALP, total bilirubin, total protein, albumin, and creatinine were monitored in individual and pooled blood. All the biochemical values were analyzed under the standard/reference range (Table 3).

Venous blood collected from individual volunteers and pooled blood was analyzed for complete blood cell count using an automated hematology analyzer within an hour of blood collection.

Table 3. Biochemical parameters of individual and pooled blood. $n=4$, Data represent Mean \pm SD.

\begin{tabular}{|c|c|c|c|c|c|c|c|c|}
\hline S.No & Parameter & Donor1 & Donor2 & Donor3 & Donor4 & Pooled & Mean \pm SD & Reference range \\
\hline 1 & Glucose & 103 & 109 & 91 & 105 & 119 & $102 \pm 7.0$ & $70-110 \mathrm{mg} / \mathrm{dl}$ \\
\hline 2 & Cholesterol & 176 & 182 & 145 & 146 & 168 & $162 \pm 19$ & $<200 \mathrm{mg} / \mathrm{dl}$ \\
\hline 3 & Triglycerides & 77 & 107 & 30 & 55 & 73 & $67 \pm 32$ & $<150 \mathrm{mg} / \mathrm{dl}$ \\
\hline$\overline{4}$ & $\begin{array}{l}\text { Alanine } \\
\text { transaminase }\end{array}$ & 17.9 & 32.7 & 18.1 & 15.7 & 19.4 & $21.1 \pm 7.8$ & 7-55IU/L \\
\hline 5 & $\begin{array}{l}\text { Aspartate } \\
\text { transaminase }\end{array}$ & 24.9 & 35.6 & 24.1 & 20.3 & 22.4 & $26.2 \pm 6.5$ & 8-48IU/L \\
\hline 6 & $\begin{array}{l}\text { Alkaline } \\
\text { phosphatase }\end{array}$ & 29 & 73 & 36 & 53 & 50 & $47 \pm 19$ & 40-129IU/L \\
\hline 7 & Total Bilirubin & 0.59 & 0.4 & 0.3 & 0.1 & 0.24 & $0.34 \pm 0.2$ & $0.1-1.2 \mathrm{mg} / \mathrm{dl}$ \\
\hline 8 & Total Protein & 9.8 & 10.6 & 11.1 & 9.5 & 10.7 & $10.2 \pm 0.7$ & $6-8.3 \mathrm{~g} / \mathrm{dl}$ \\
\hline 9 & Albumin & 6.4 & 7.2 & 7.4 & 6.3 & 7.2 & $6.8 \pm 0.5$ & $3.5-5 \mathrm{~g} / \mathrm{dl}$ \\
\hline 10 & Creatinine & 1.15 & 1.46 & 1.01 & 1.1 & 1.23 & $1.18 \pm 0.1$ & $0.84-1.21 \mathrm{mg} / \mathrm{dl}$ \\
\hline
\end{tabular}


The hematological and biochemical parameters of individual and pooled blood were found to be under normal range, and this pooled blood was used as a test system for the detection of IL-1 $\beta$. Hematology parameters of all donors and pooled blood were found to be within the standard/reference range (Table 4).

Table 4. Hematology parameters of individual and pooled blood.WBC; white blood cells, RBC: red blood cells, HGB; hemoglobin, HCT; hematocrit, MCV; Mean corpuscular volume, MCH; Mean corpuscular hemoglobin, MCHC; mean corpuscular hemoglobin concentration. $n=4$, Data represent Mean \pm SD.

\begin{tabular}{l|l|l|l|l|l|l|l} 
Parameter & Donor1 & Donor2 & Donor3 & Donor4 & Pooled & $\begin{array}{l}\text { Mean } \\
\pm \text { SD }\end{array}$ & $\begin{array}{l}\text { Reference } \\
\text { range }\end{array}$ \\
\hline WBC $\left(\mathrm{x} 10^{3} / \mu \mathrm{l}\right)$ & 7.54 & 8.3 & 6.72 & 7.12 & 6.72 & $7.42 \pm 0.67$ & $4-10$ \\
\hline Lym\% & 40.7 & 36.1 & 52.3 & 33.3 & 38.8 & $40.6 \pm 8.3$ & $18-45$ \\
\hline Gran\% & 54.1 & 60.3 & 41.3 & 62.9 & 57.2 & $54.65 \pm 9.6$ & $50-70$ \\
\hline Mid\% & 5.2 & 3.6 & 6.4 & 3.8 & 4.0 & $4.75 \pm 1.3$ & $3-10$ \\
\hline RBC $(\mathrm{x} 10 \% / \mathrm{mm} 3)$ & 4.33 & 6.02 & 4.03 & 4.33 & 4.06 & $4.67 \pm 0.9$ & $4.50-5.50$ \\
\hline $\mathrm{Hb}(\mathrm{g} / \mathrm{dl})$ & 13.7 & 16.7 & 12.5 & 10.8 & 14.1 & $13.4 \pm 2.4$ & $13.0-16.0$ \\
\hline $\mathrm{HCT}(\%)$ & 38.8 & 47.6 & 36.1 & 28.3 & 32.7 & $37.7 \pm 7.9$ & $40.0-54.0$ \\
\hline $\mathrm{MCV}(\mu \mathrm{m} 3)$ & 89.7 & 79.0 & 89.7 & 65.5 & 80.7 & $80.9 \pm 11.4$ & $75-95$ \\
\hline $\mathrm{MCH}(\mathrm{pg})$ & 31.7 & 27.7 & 31.2 & 22.7 & 34.7 & $28.3 \pm 4.1$ & $30-35$ \\
\hline $\mathrm{MCHC}(\mathrm{g} / \mathrm{dl})$ & 35.4 & 35.0 & 34.7 & 34.7 & 43.1 & $34.9 \pm 0.3$ & $30-35$ \\
\hline $\mathrm{PLT}\left(\mathrm{x} 10^{3} / \mu \mathrm{l}\right)$ & 331 & 244 & 216 & 344 & 259 & $283 \pm 63$ & $150-500$
\end{tabular}

\subsection{Detection of IL-1 $\beta$ by ELISA.}

The IL-1 $\beta$ release from pooled human blood after LPS (1EU/ml and 5EU/ml), LTA $(0.1 \mu \mathrm{g} / \mathrm{ml}$ and $1 \mu \mathrm{g} / \mathrm{ml})$, PHA $(15 \mu \mathrm{g} / \mathrm{ml}$ and $30 \mu \mathrm{g} / \mathrm{ml})$ and TNP $(15 \mu \mathrm{g} / \mathrm{ml}$ and $30 \mu \mathrm{g} / \mathrm{ml})$ exposure was analyzed for an incubation period of $8 \mathrm{~h}$. Pooled blood without any pyrogenic stimulant was served as negative control and was kept along with every batch of the assay. No significant increase in IL-1 $\beta$ levels was noticed in negative control for the entire period of incubation. The optical density (O.D) values were measured at $0,2,4,6$, and $8 \mathrm{~h}$ using an ELISA plate reader. The O.D. values were plotted against time for estimating IL-1 $\beta$ released from pooled blood. Compared to the non-stimulated control, LPS stimulated blood showed a significant increase in the release of IL-1 $\beta$. It was noted that the release of IL- $1 \beta$ begins at $2 \mathrm{~h}$ following stimulation with $1 \mathrm{EU} / \mathrm{ml}$ of LPS and is elevated until $8 \mathrm{~h}$. Exposure of $5 \mathrm{EU} / \mathrm{ml}$ of LPS induced rapid release of IL- $1 \beta$ within $1 \mathrm{~h}$ and reaches the maximum at $2 \mathrm{~h}$. These results are consistent with the earlier report of Banerjee et al. in 2011, using human whole blood assay [21]. It was also noted that IL- $1 \beta$ induced by $1 \mu \mathrm{g} / \mathrm{ml}$ LTA reached the maximum at $1 \mathrm{~h}$ of induction, and $0.1 \mu \mathrm{g} / \mathrm{ml}$ LTA took a period of 2 to $4 \mathrm{~h}$ for maximum release. In stimulation with PHA and TNP, a maximum IL- $1 \beta$ release was observed within $0-2 \mathrm{~h}$ at $30 \mu \mathrm{g} / \mathrm{ml}$ concentration. The delayed response of IL-1 $\beta$ released by blood cells on the challenge with a low concentration of pyrogens may be due to the insufficient quantity of toxicants to occupy the TLR receptors on monocytes/ macrophages to activate immune signaling to the slow release of synergistically acting cytokines from immune cells. Another study reported from Dinarello supports a sudden increase in the IL- $1 \beta$ mRNA expression level and gradually subside due to their lower half-life period or by the action of their transcriptional repressor synthesis. So in the case of higher concentration of endotoxin exposure, it is observed that much faster expression of IL-1 $\beta$ activation occurred compared to a lower concentration of endotoxins [22]. The detection of chemical toxicant (non- endotoxic pyrogen) demonstrated in the present study is advantageous over LAL assay as it can detect only Gram-negative endotoxin. The study conducted in the pooled blood reaction strongly correlated with the previous report based on 
the human whole blood assay [20]. The advantage of human whole blood assay over the other assays relies on the specific and effective detection of Gram-negative, Gram-positive, biological, and chemical pyrogens present in any type of material. Thus, the indigenously developed ELISA method for pyrogen detection allows a simple, much faster, reliable, costeffective system detecting endotoxin and non-endotoxin pyrogens. Figure 2 represents the IL$1 \beta$ released from pooled whole blood after stimulation with LPS, LTA, PHA, and TNP.

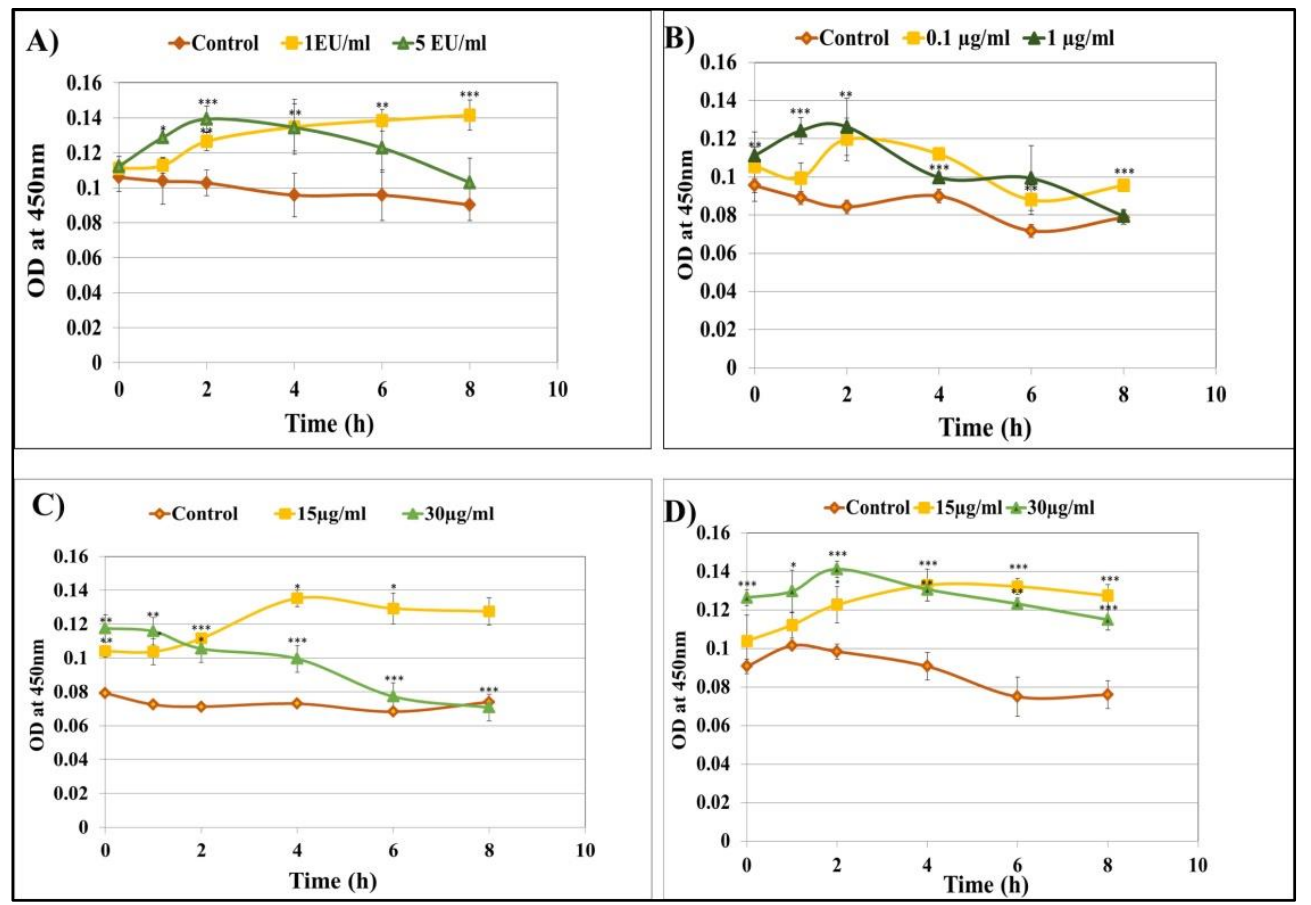

Figure 2. The IL-1 $\beta$ release from pooled blood by stimulating with A) LPS ( 1 and 5EU/ml), B) LTA 0.1 and $1 \mu \mathrm{g} / \mathrm{ml})$, C) PHA (15 and 30 $\mu \mathrm{g} / \mathrm{ml})$ and D) TNP $(15$ and $30 \mu \mathrm{g} / \mathrm{ml})$ using ELISA. Reactions were monitored for $8 \mathrm{~h}$ at $2 \mathrm{~h}$ intervals. $\mathrm{n}=3$, Data represents Mean $\pm \mathrm{SD},{ }^{*} \mathrm{p}<0.05, * * \mathrm{p}<0.01, * * * \mathrm{p}<0.001$.

\subsection{Analysis of pyrogenicity in rabbits.}

\subsubsection{Pyrogenic response after LPS administration.}

The pyrogenic effect of endotoxin was studied using rabbits. All the animals were acclimatized before the administration of LPS. The body weights of the animals were recorded individually before acclimatization and the day of the experiment. Animals did not show any abnormalities throughout the experiment after injection. The test sample (physiological saline containing lipopolysaccharides) administrated in rabbits showed a rise in temperature of $0.97^{\circ} \mathrm{C}$

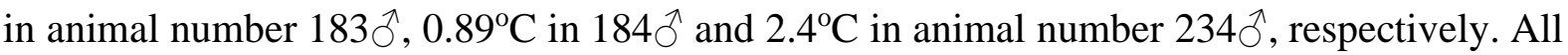
the test sample injected rabbits showed a rise in rectal temperature of $0.5^{\circ} \mathrm{C}$ or above the basal temperature during the observation period. The mean value of temperature rise observed in three rabbits is $1.42 \pm 0.69^{\circ} \mathrm{C}$ (Table 5).

Table 5. Rectal temperature of rabbits before and after administration of LPS, $n=3$, Data represents Mean \pm SD. $* \mathrm{p}<0.05, * * \mathrm{p}<0.01, * * * \mathrm{p}<0.001$.

\begin{tabular}{|c|c|c|c|c|}
\hline Particulars & $183 \overbrace{}^{\lambda}$ & $184{ }^{\lambda}$ & $234{ }^{\lambda}$ & Mean \pm SD \\
\hline Animal body weight $(\mathrm{g})$ & 2440 & 2630 & 2605 & $2588 \pm 84$ \\
\hline Temperature $30^{\prime}$ prior to test $\left({ }^{\circ} \mathrm{C}\right)$ & 39.23 & 39.15 & 38.91 & $39 \pm 0.13$ \\
\hline Volume of injection (ml) & 24.40 & 26.30 & 26.05 & $25.5 \pm 0.84$ \\
\hline Temperature, $60^{\prime}$ after injection $\left({ }^{\circ} \mathrm{C}\right)$ & 40.17 & 40.02 & 40.35 & $40.18 \pm 0.13 * *$ \\
\hline Temperature, $90^{\prime}$ after injection $\left({ }^{\circ} \mathrm{C}\right)$ & 40.19 & 40.04 & 40.72 & $40.31 \pm 0.29 * *$ \\
\hline Temperature, $120^{\prime}$ after injection $\left({ }^{\circ} \mathrm{C}\right)$ & 40.13 & 40.02 & 40.28 & $40.14 \pm 0.10^{*}$ \\
\hline
\end{tabular}




\begin{tabular}{l|c|c|c|c} 
Particulars & $\mathbf{1 8 3}{ }^{\lambda}$ & $\mathbf{1 8 4}{ }^{\lambda}$ & $\mathbf{2 3 4}{ }^{\lambda}$ & Mean \pm SD \\
\hline Temperature, $150^{\prime}$ after injection $\left({ }^{\circ} \mathrm{C}\right)$ & 40.20 & 40.00 & 40.32 & $40.17 \pm 0.13^{*}$ \\
\hline Temperature, $180^{\prime}$ after injection $\left({ }^{\circ} \mathrm{C}\right)$ & 40.17 & 40.03 & 41.31 & $40.50 \pm 0.57$ \\
\hline Average Rise in temperature $\left({ }^{\circ} \mathrm{C}\right)$ & 0.97 & 0.89 & 2.40 & $1.42 \pm 0.69$
\end{tabular}

Rabbits are the most suitable model for pyrogenic response. In the present study, in vivo response to LPS begins within half an hour and lasts for more than $3 \mathrm{~h}$. Rectal temperature is significantly raised from the baseline temperature of $39.12 \pm 0.175$ to a maximum temperature of $40.58 \pm 0.70$. LPS is a well-known pyrogen, and its activity depends on pyrogenic cytokines released from the immune cells. Elevation in body temperature is associated with variation in the thermoregulatory mechanism of the CNS. There are reports of a time-dependent rise in rectal temperature following the intravenous (i. v), intraperitoneal (i. p), intramuscular (i. m), and subcutaneous (s. c) administration of LPS in rabbits. LPS mediated pyrogen response is independent of the route of exposure. The peak value of rectal temperature was reported between 60-210 $\min [23]$.

Endogenous pyrogens (EPs) released following intravenous administration of LPS, poly (I: C), and Newcastle disease virus (NDV) was found to induce an immediate rise of rectal temperature in rabbits. With PGE2 and cyclic AMP, EPs enhance the magnitude of pyrogeninduced fever and are the classical pathway of pyrogen response. Almost all exogenous pyrogens follow a similar pathway of fever induction, where EPs, PGE2, and cAMP lead to variation in the thermoregulatory mechanism of the hypothalamus [24,25]. Conversely, EPs, PGE2, and cAMP-mediated fever stimulation were not detected in animals with induced hyperthermia. It is informative that hyperthermia associated with environmental or other factors follows the alternate temperature induction pathway compared to exogenous Pyrogens [26]. Hyperthermia has shown enhanced fever and febrile reactions in rabbits challenged with LPS. Heat stress facilitates leakage of LPS from intestinal cells into blood circulation, exaggerating pyrogenic fever in stressed animals compared to non-stressed animals. In heatstressed animals, LPS induced fever is not correlated with the serum concentration of IL-1 $\beta$ and TNF- $\alpha$. Hence, it was stated that enhanced fever response in the heat-stressed animal depends on the amount of endotoxin leaked from the damaged intestinal lining to blood circulation [27].

It was well documented that human monocyte-derived EPs are potent stimulators of fever in rabbits. EPs administrated either i.v or intracerebroventricular (i.c.v) route can induce pyrogenic fever. However, the animals who received EPs via i.v showed more variation than animals who received i.c.v challenge. The study depicts the mode of action of EPs at the CNS level, where it interacts with specific receptors and directly affects the thermostatic mechanism. It was suggested that variability in fever response following i.v administration is due to the low level of EP-receptor interaction or difference in permeability of EPs through the Blood-Brain Barrier (BBB) [28].

\subsubsection{Hematological parameters.}

The immune system is a wide network of organs and cells that continuously monitor foreign invaders to prevent entry into the host system. When an antigenic substance enters the body, there will be a network of immune reactions, protecting the host from adverse reactions. During immune activation, there will be a variation of hematological and biochemical parameters in the host body. In the present study, rabbit blood was analyzed for hematological and biochemical parameters before and after endotoxin administration. Venous blood was 
collected from the marginal ear vein of animals before and after administration of LPS and subjected to hematological analysis. The study results indicated that white blood cell count was decreased in LPS treated animals compared to control. RBC count, hemoglobin concentration, blood cell volume, and platelet count remained within normal range and comparable to control (Table 6).

Table 6. Hematology parameters of rabbits exposed to LPS. WBC; white blood cells, RBC: red blood cells, HGB; hemoglobin, HCT; hematocrit, MCV; Mean corpuscular volume, $\mathrm{MCH}$; Mean corpuscular hemoglobin, $\mathrm{MCHC}$; mean corpuscular hemoglobin concentration, $\mathrm{n}=3$. The data represent the mean $\pm \mathrm{SD}$.

\begin{tabular}{l|l|l|l} 
S.No & Parameter & Control & Test \\
\hline 1 & WBC $\left(10^{3} / \mathrm{mm}^{3}\right)$ & $8.3 \pm 1.15$ & $4.3 \pm 2.05$ \\
\hline 2 & RBC $\left(10^{6} / \mathrm{mm}^{3}\right)$ & $6.32 \pm 1.33$ & $5.93 \pm 0.83$ \\
\hline 3 & HGB $(\mathrm{g} / \mathrm{dl})$ & $13.9 \pm 2.6$ & $14 \pm 2.35$ \\
\hline 4 & HCT $(\%)$ & $37.6 \pm 8.05$ & $36.6 \pm 6.17$ \\
\hline 5 & MCV $\left(\mu \mathrm{m}^{3}\right)$ & $59.4 \pm 1.95$ & $61.5 \pm 1.75$ \\
\hline 6 & MCH $(\mathrm{pg})$ & $22.06 \pm 1.51$ & $23.5 \pm 0.7$ \\
\hline 8 & MCHC $(\mathrm{g} / \mathrm{dl})$ & $37.06 \pm 1.5$ & $38.2 \pm 0.34$ \\
\hline & Platelets $\left(10^{3} / \mathrm{mm}^{3}\right)$ & $155 \pm 25$ & $230 \pm 44$
\end{tabular}

White blood cells (WBC) are the defenders, which phagocytose foreign particles or produce antibodies against antigens to neutralize them. In the present study, exposure to LPS in rabbits caused a decrease in WBC count that of control. Burrow reported similar findings in 1979, where lymphocyte count was drastically reduced following the LPS challenge in equine species. Leucopenia is a common phenomenon following LPS exposure in vivo. Leucopenia persists for $3 \mathrm{~h}$ and becomes normal within $12 \mathrm{~h}$ of LPS challenge. The packed cell volume (PCV) was unchanged following exposure of 0.2-20 $\mu \mathrm{g} / \mathrm{kg}$ LPS [29]. The present study agrees with the above findings, where $\mathrm{RBC}, \mathrm{Hb}, \mathrm{HCT}, \mathrm{MCV}, \mathrm{MCH}$, and $\mathrm{MCHC}$ parameters are well comparable to control. Lymphocytes and monocytes recruited at the site of inflammation propagate signals and attribute various cellular defense mechanisms, including chemotaxis, adhesion, invasion, and phagocytosis. It was reported that LPS exposure leads to a significant reduction of lymphocytes and monocytes in rabbits, where the neutrophil count was found to be normal or slightly increased after $4 \mathrm{~h}$. Even though primary exposure to LPS can induce leucopenia, repeated exposure to the same endotoxin will give rise to leukocytosis due to immune tolerance [30].

\subsubsection{Biochemical parameters.}

Endotoxemia is a condition where bacterial toxins circulate in the blood and negatively affect the function of vital organs. Endotoxemia-related dysfunction of the liver, kidney, heart, lungs, and brain potentially leads to a fatal condition. In most mammalian species, alanine transaminase (ALT), aspartate transaminase (AST), and Gamma-glutamyltransferase (GGT) are liver-specific enzymes; hence, its elevation indicates damage to the hepatic system. The present study evaluated the biochemical parameters such as blood glucose, cholesterol, protein, liver enzymes, and creatinine following the LPS challenges to investigate cellular metabolism changes and potential damage to the organs. It was observed that there is a significant rise in the concentration of glucose, triglycerides, alanine transaminase, aspartate transaminase, alkaline phosphatase, and creatinine in treated animals compared to control. The result indicated a significant change in biochemical parameters and indicated malfunctioning of the liver and kidney (Table 7). 
Dyshomeostasis of glucose metabolism is a prominent feature of endotoxemia. As per the report of Nagarajaet al., in 1979, i.v administration of endotoxin significantly affected glucose metabolism, liver functions, and hematological parameters in calves.

Table 7. Biochemical parameters of rabbits exposed to LPS. The data represent mean $\pm \mathrm{SD}, \mathrm{n}=3$. The asterisk above values denotes a statistically significant difference compared to the control group $(* \mathrm{p}<0.05)$.

\begin{tabular}{l|l|c|c|c} 
S.No & Parameter & Control & Test & Reference range (Melillo,2007) \\
\hline 1 & Glucose $(\mathrm{mg} / \mathrm{dl})$ & $137.3 \pm 4.66$ & $261 \pm 14.0^{*}$ & $75-155$ \\
\hline 2 & Cholesterol $(\mathrm{mg} / \mathrm{dl})$ & $21.5 \pm 14.84$ & $24 \pm 14.14$ & $10-80$ \\
\hline 3 & Triglycerides $(\mathrm{mg} / \mathrm{dl})$ & $57 \pm 8.48$ & $129.5 \pm 16.2^{*}$ & $7-205$ \\
\hline 4 & Alanine transaminase (IU/L) & $46.85 \pm 1.06$ & $182.15 \pm 11.8^{*}$ & $45-80$ \\
\hline 5 & Aspartate transaminase (IU/L) & $42.3 \pm 9.33$ & $226.8 \pm 74.9^{*}$ & $35-130$ \\
\hline 6 & Alkaline phosphatase (IU/L) & $58 \pm 8.48$ & $88.5 \pm 48.7$ & $12-96$ \\
\hline 7 & Total Protein $(\mathrm{g} / \mathrm{dl})$ & $8.65 \pm 0.21$ & $8.75 \pm 0.07$ & $5.4-7.5$ \\
\hline 8 & Albumin $(\mathrm{g} / \mathrm{dl})$ & $3.7 \pm 0.42$ & $3.6 \pm 0.14$ & $2.7-5.0$ \\
\hline 9 & Creatinine $(\mathrm{mg} / \mathrm{dl})$ & $1.92 \pm 0.11$ & $2.835 \pm 0.77$ & $0.5-2.5$
\end{tabular}

It was noted that endotoxin shock-induced immediate hyperglycemia within $15 \mathrm{~min}$ and persisted for 3h. An elevated level of AST and lysosomal enzymes (acid phosphatase and /3glucuronidase) were also reported. Severe hemorrhage in the brain, lungs, liver, and kidney indicated disseminated intravascular coagulation induced by LPS [31].

There are reports of a significant increase in the concentration of AST, ALT, GGT, triglycerides, urea, and creatinine in rabbits on the challenge with a high dose of LPS. It was inferred that LPS is capable of causing lipid metabolism disorders and damage to vital organs (liver and kidney) [32]. However, these results are different from those found by Kootet al., 2016 and Peñaililloet al., 2016, where AST, bilirubin, creatinine, and GGT values in endotoxemic rabbits were found to be comparable to that of control. Similar results were reported in piglets challenged with LPS, where AST and ALT values were significantly increased within $4 \mathrm{~h}$ following administration. Proteins synthesized from the liver, especially $\alpha 1$-globulins and sialic acid, significantly increased and are the potent indicator of acute-phase inflammatory reaction. Extrarenal damage was noted with increased blood urea level. However, creatinine values were comparable to that of normal in the initial phase of infection. Dyshomeostasis of glucose, represented as hyperglycemia, followed by hypoglycemia in piglets [33], agrees with the observations of the present study.

\subsubsection{Expression of cytokine genes in rabbit PBMC.}

Expression of transcription factor NFKB and pro-inflammatory cytokines (IL-1 $\beta$ and IL-8) genes were analyzed in PBMC isolated from rabbit blood. NFKB is the major transcription factor responsible for inflammatory cytokine genes' active transcription and expression [34]. Here, LPS is a stimulator of immune response in rabbits. Since PBMC, especially monocytes and macrophages are the active producers of cytokines, expression of NFкB, IL-1 $\beta$ and IL-8 were studied in PBMC isolated from rabbit blood before and after

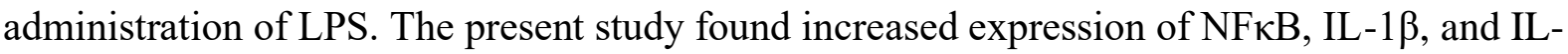
8 following LPS administration (Figure 3). These observations suggest LPS induced immune activation in PBMC. Typically, NFאB is found in the cell cytoplasm as an inactive form bound with IкB. When there is an interaction of foreign substances or PAMPs with TLR, there will

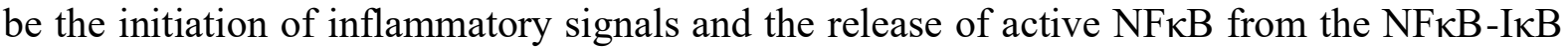
complex [35]. Translating released NFאB into the nucleus will result in the binding of these transcription factors to the promoter region of genes specific for cytokines, chemokines, and 
coagulation factors. NFKB expression has a direct role in immune activation, cell differentiation, and cell survival. It was reported that blood samples were collected from rabbits, intravenously administrated with staphylococcal enterotoxins. A showed a significant increase in NFאB expression compared to untreated control. Staphylococcus superantigens are pyrogenic. They interact principally with T cells and activate the release of TNF- $\alpha$, IL-1, and IFNs. Release and interaction of pro-inflammatory cytokines, in turn, activate NFkB translocation and propagation of immune response [36]. NFאB also plays a critical role in generating cerebral vasospasm with respect to inflammatory cerebral hemorrhage in rabbits. Inflammation involves a series of events, and its magnitude depends on cellular interaction, cytokine production, and intracellular signaling. Subarachnoid hemorrhage is a stimulus of vascular inflammation and was associated with increased expression of NFkB, IL-1 $\beta$, and TNF- $\alpha$ [37].

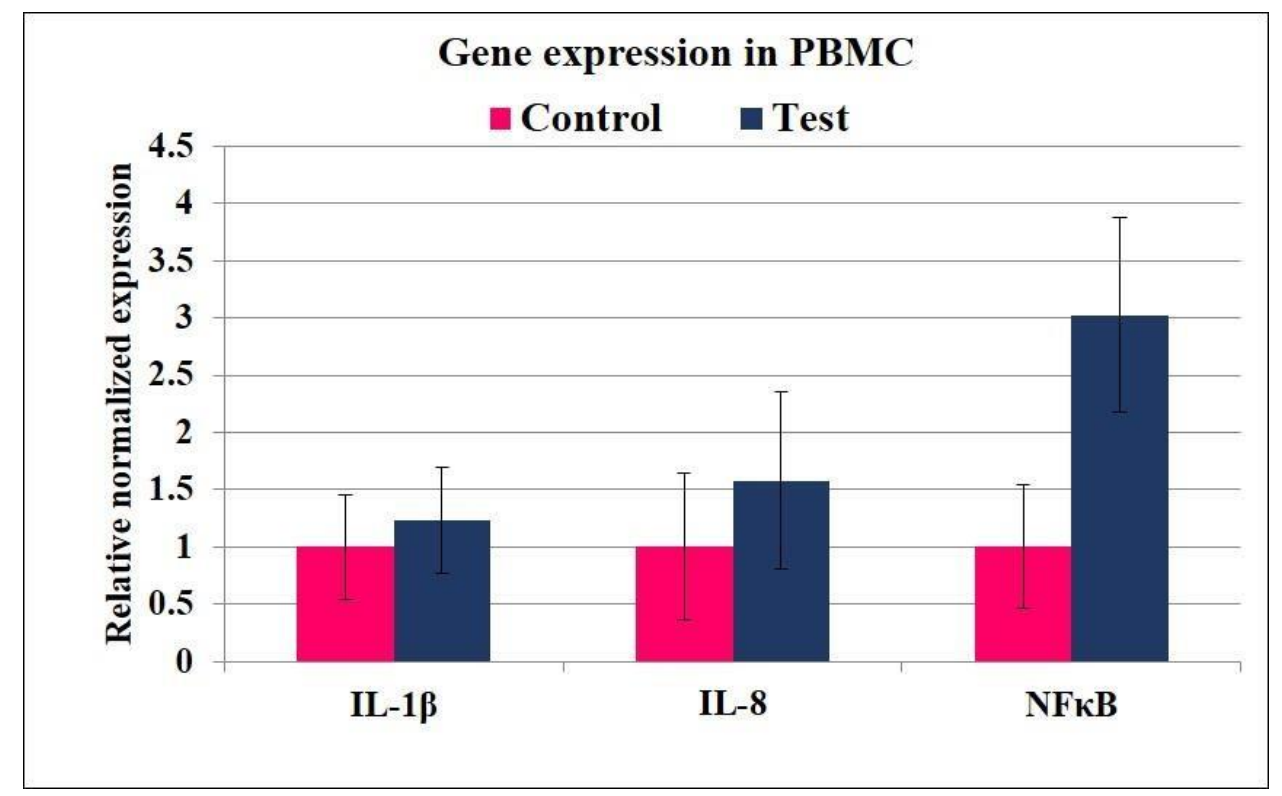

Figure 3. Expression of IL-1 $\beta$, IL-8, and NFKB genes from PBMC following i.v. exposure of LPS to rabbits relative to GAPDH (housekeeping gene). $n=3$, Data represents the mean \pm SD.

\subsubsection{Analysis of cytokines from rabbit blood serum.}

Cytokine family is an integrated system with a network of multiple cytokines, which mediates immune response against infection or inflammation. In the IL- 1 family, IL- $1 \beta$ is the potent pyrogenic cytokine that acts on CNS to induce fever/febrile reaction. Clinton et al., 1991 demonstrate the pathological effect of IL-1 $\beta$ in inflammatory atherosclerosis, where increased expression of the IL-1 $\beta$ gene was found in vascular tissues of LPS challenged rabbits [38]. IL$1 \beta$ having molecular weight $17 \mathrm{kDa}$, is the biologically active form and was found to be elevated in LPS challenged animals directs its substantial role in infection and vascular injury [39]. The present study investigated the release of pro-inflammatory cytokines IL- $1 \alpha$, IL- $1 \beta$, and TNF- $\alpha$ following i.v. administration of LPS in rabbits (Figure 4). LPS challenge significantly increased cytokine release from immune cells. The present study observed 2.7 fold increases in IL-1 $\alpha$, 2.8 fold in IL-1 $\beta$, and 4.8 fold in TNF- $\alpha$ concentration in LPS exposed rabbits compared to control. It was reported that the circulating level of IL-1 $\beta$ and TNF- $\alpha$ have a role in febrile response and tolerance to LPS administration in rabbits. Fever response is found in rabbits following increased production of IL- $1 \beta$ and TNF- $\alpha$, where tolerance is associated with a low level of these cytokines in circulation. It was noted that PBMCs are the major secretors of IL- 
$1 \beta$ and are responsible for febrile hyperresponsiveness in rabbits, 7days post-LPS administration. A rise in serum levels of IL- $1 \beta$ and TNF- $\alpha$ follow independent periods despite their similarities in fever induction potential. The peak value of TNF- $\alpha$ was observed within 60 minutes, where IL-1 $\beta$ reached peak rise only after 180 minutes of LPS challenge [40].

LPS interaction with TLR-4 and CD14 activate inflammatory signals through coordinate action of various pro-inflammatory cytokines, including TNF- $\alpha$. Reports suggest that LPS challenge in rabbits elevated TNF- $\alpha$ within 60 min. However, pretreatment with IL-1 reduced LPS induced TNF- $\alpha$ production even it enhanced TNF- $\alpha$ in non-treated rabbits. This observation was explained in such a way that IL-1 could induce the release of corticosteroids that intern down-regulate the expression of TNF- $\alpha$ mRNA along with IL-1 [41]. TNF- $\alpha$ is a pleiotropic cytokine that activates the synthesis and release of other cytokines from cells and organs [42]. The release of pro-inflammatory cytokines has a role in the regulation of hormone secretion and organ functions. A recent study conducted by Qin et al., 2008 reported that i.p administration of LPS in mice showed a profound increase in IL- $1 \beta$, TNF- $\alpha$, and MCP-1 level in serum and vital organs such as the liver and brain. Kupffer cells in the liver secrete a major part of IL-1 $\beta$ and release it into the blood circulation. These cytokines cross BBB and elicit an inflammatory response at the CNS level. It was also reported that endogenous leukemia inhibitory factor (LIF) has a protective role in endotoxemic shock. It was noted that i.p exposure of LPS significantly increased the serum concentration of TNF- $\alpha$ and IL- 6 in mice, where the concentration of IL-10 was diminished considerably. These effects were prominent in mice lacking LIF compared to the wild type. An unresolved increase in TNF- $\alpha$, IL-1 $\beta$, IL-6, etc., may result in endotoxemic shock and death [43].

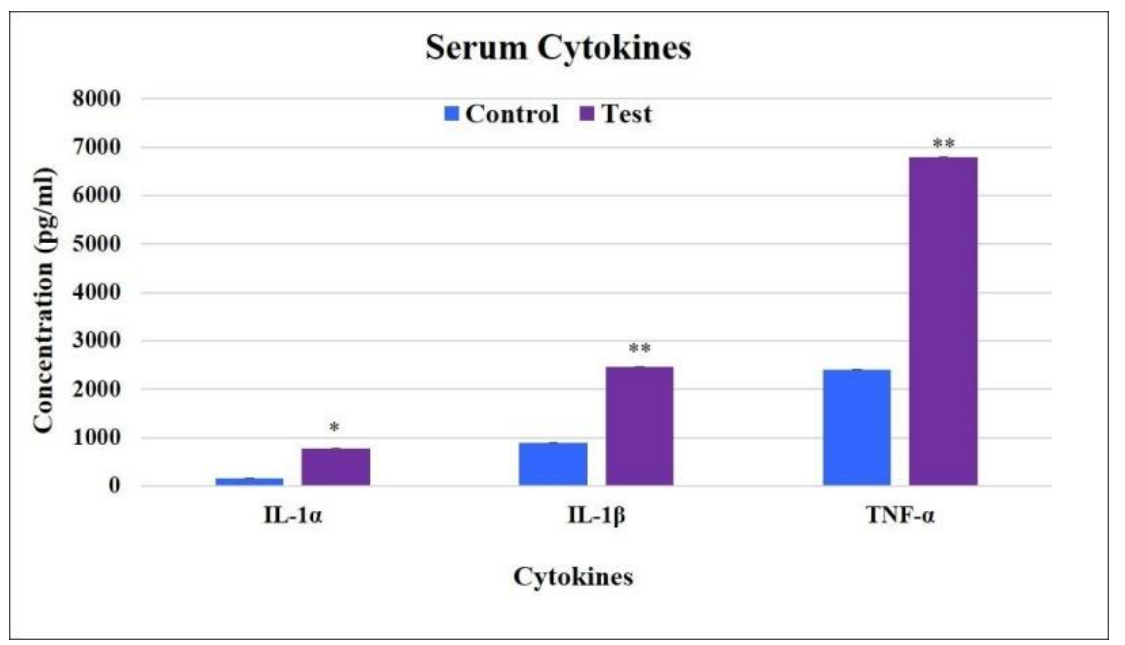

Figure 4. Analysis of serum cytokines from rabbits exposed to LPS ( $n=3)$. The data represent the mean \pm SD. Asterisk denotes statistically significant difference $(* \mathrm{p}<0.05$ and $* * \mathrm{p}<0.01)$.

Anti-inflammatory cytokines or other molecules, which suppress the production and action of pyrogenic cytokines, can attenuate fever and febrile reactions following endotoxin challenge [44]. LPS administration is a stimulator of IL-1 $\beta$ and eicosanoids production from immune cells, peripheral organs, and the brain. Ledeboer et al., 2002 found significant elevation of IL-1 $\beta$ following LPS administration in rat blood, liver, spleen, and pituitary gland. In addition to IL-1 $\beta$, a positive correlation of hyperthermic reaction and elevation of IL- 6 and TNF- $\alpha$ was found in rats that underwent LPS challenge. It was noted that peripheral administration of anti-inflammatory cytokine IL-10 markedly attenuated the production of pyrogenic cytokines. IL-10 mediated attenuation of fever is found to mediate by interfering 
with the humoral and neural signaling of IL-1 $\beta$ and other pyrogenic cytokines to the brain [45]. Reports indicate that an acute inflammatory reaction initiated by LPS is progressed quickly in mice and resolves within $72 \mathrm{~h}$. LPS administration induced a rapid rise in serum TNF- $\alpha$ and IL6, which play a pivotal role in liver dysfunction [46]. Correlation with our findings, it was reported that TNF- $\alpha$ plays a role in dyshomeostasis of glucose metabolism following LPS challenge [47]. Inflammatory cytokines also have a role in mitochondrial activity and the associated generation of ROS inside the cells. LPS is a potent activator of systemic inflammation, inducing cytokines, oxidative stress, immune cell infiltration, and apoptotic death in vital organs.

\section{Conclusions}

The present study clearly emphasizes the need for an alternate detection system to reduce the complications associated with pyrogenic contaminants possibly. Unlike other methods listed in the pharmacopeia, here, the study provides a better opportunity to detect all types of possible pyrogenic contaminants using pooled human blood for pyrogenic induction and quantification using indigenously developed ELISA method. The method provides an uninterrupted supply of blood with fewer interpersonal variations. The pyrogenic responses observed in the rabbit after LPS administration made a clear indication of the inflammatory cytokine expression level, a significant rise in body temperature, and also a change in biochemical parameters as an indication of liver and kidney malfunctioning. The study demonstrates the underlying mechanism and severe adverse effects associated with pyrogenic contaminations. So the depicted alternate system for testing pyrogenicity is a great advantage for biomedical research and health care system to reduce animal experimentations.

\section{Funding}

Prajitha N thanks to the Council of Scientific and Industrial Research, New Delhi, for the SRF Fellowship.

\section{Acknowledgments}

The authors wish to express their thanks to the Director and Head, Biomedical Technology Wing, SreeChitraTirunal Institute for Medical Sciences and Technology, Trivandrum, Kerala, India, for their support in providing the infrastructure to carry out this work. The authors are thankful to Mr. AkhilVenugopal, Mr. S Shaji, and Mr. G Harikumar for all the technical support.

\section{Conflicts of Interest}

The authors declare no conflict of interest.

\section{References}

1. Mazgaeen, L.; Gurung, P. Recent Advances in Lipopolysaccharide Recognition Systems. International Journal of Molecular Sciences 2020, 21, https://doi.org/10.3390/ijms21020379.

2. Dinarello, C.A.; Wolff, S.M. Pathogenesis of Fever in Man. New England Journal of Medicine 1978, 298, 607-612, https://doi.org/10.1056/NEJM197803162981107.

3. Dinarello, C.A. Inflammatory cytokines: interleukin-1 and tumor necrosis factor as effector molecules in autoimmune diseases. Current Opinion in Immunology 1991, 3, 941-948, https://doi.org/10.1016/s09527915(05)80018-4. 
4. Mul Fedele, M.L.; Aiello, I.; Caldart, C.S.; Golombek, D.A.; Marpegan, L.; Paladino, N. Differential Thermoregulatory and Inflammatory Patterns in the Circadian Response to LPS-Induced Septic Shock. Frontiers in Cellular and Infection Microbiology 2020, 10, https://doi.org/10.3389/fcimb.2020.00100.

5. Appiah, M.G.; Park, E.J.; Akama, Y.; Nakamori, Y.; Kawamoto, E.; Gaowa, A.; Shimaoka, M. Cellular and Exosomal Regulations of Sepsis-Induced Metabolic Alterations. International Journal of Molecular Sciences 2021, 22, https://doi.org/10.3390/ijms22158295.

6. Saoraya, J.; Musikatavorn, K.; Puttaphaisan, P.; Komindr, A.; Srisawat, N. Intensive fever control using a therapeutic normothermia protocol in patients with febrile early septic shock: A randomized feasibility trial and exploration of the immunomodulatory effects. SAGE Open Medicine 2020, 8, 1-9, https://doi.org/10.1177/2050312120928732.

7. European Pharmacopoeia. clause 2.6.8 Pyrogens, 1997.

8. Askari, V.R.; Rahimi, V.B.; Zargarani, R.; Ghodsi, R.; Boskabady, M.; Boskabady, M.H. Anti-oxidant and anti-inflammatory effects of auraptene on phytohemagglutinin (PHA)-induced inflammation in human lymphocytes. Pharmacological Reports 2021, 73, 154-162, https://doi.org/10.1007/s43440-020-00083-5.

9. Ozdogan, H.; Ugurlu, S.; Uygunoglu, U.; Tutuncu, M.; Gul, A.; Akman, G.; Siva, A. The efficacy of antiIL-1 treatment in three patients with coexisting familial Mediterranean fever and multiple sclerosis. Multiple Sclerosis and Related Disorders 2020, 45, https://doi.org/10.1016/j.msard.2020.102332.

10. Chan, A.H.; Schroder, K. Inflammasome signaling and regulation of interleukin-1 family cytokines. Journal of Experimental Medicine 2019, 217,1-10, https://doi.org/10.1084/jem.20190314.

11. Mailhot, B.; Christin, M.; Tessandier, N.; Sotoudeh, C.; Bretheau, F.; Turmel, R.; Pellerin, È.; Wang, F.; Bories, C.; Joly-Beauparlant, C.; De Koninck, Y.; Droit, A.; Cicchetti, F.; Scherrer, G.; Boilard, E.; SharifNaeini, R.; Lacroix, S. Neuronal interleukin-1 receptors mediate pain in chronic inflammatory diseases. Journal of Experimental Medicine 2020, 217, 1-18, https://doi.org/10.1084/jem.20191430.

12. European Pharmacopoeia, clause 2.6.30 Monocyte-activation test. 2010.

13. Dinarello, C.A. Proinflammatory Cytokines. CHEST 2000, 118, 503-508, https://doi.org/10.1378/chest.118.2.503.

14. Beutler, B.; Rietschel, E.T. Innate immune sensing and its roots: the story of endotoxin. Nature Reviews Immunology 2003, 3, 169-176, https://doi.org/10.1038/nri1004.

15. Wang, J.E.; Dahle, M.K.; McDonald, M.; Foster, S.J.; Aasen, A.O.; Thiemermann, C. Peptidoglycan and Lipoteichoic Acid in Gram-Positive Bacterial Sepsis: Receptors, Signal Transduction, Biological Effects, and Synergism. Shock 2003, 20, 402-414, https://doi.org/10.1097/01.shk.0000092268.01859.0d.

16. The United States Pharmacopeia USP 31, NF 26, 151 Pyrogen Test.2008.

17. Hartung, T.; Wendel, A. Detection of pyrogens using human whole blood. ALTEX 1995, 12, 70-75.

18. Dinarello, C.A.; Cannon, J.G.; Wolff, S.M.; Bernheim, H.A.; Beutler, B.; Cerami, A.; Figari, I.S.; Palladino, M.A., Jr.; O’Connor, J.V. Tumor necrosis factor (cachectin) is an endogenous pyrogen and induces production of interleukin 1. Journal of Experimental Medicine 1986, 163, 1433-1450, https://doi.org/10.1084/jem.163.6.1433.

19. Mohanan, P.; Siddharth, B.; Geetha, C. An indigenously developed human whole blood assay for pyrogenicity: A comparative assessment. Toxicology Letters 2010, 196, https://doi.org/10.1016/j.toxlet.2010.03.457.

20. Daneshian, M.; von Aulock, S.; Hartung, T. Assessment of pyrogenic contaminations with validated human whole-blood assay. Nature Protocols 2009, 4, 1709-1721,https://doi.org/10.1038/nprot.2009.159.

21. Banerjee, S.; Mohanan, P.V. Inflammatory response to pyrogens determined by a novel ELISA method using human whole blood. Journal of Immunological Methods 2011, 369, 146-153, https://doi.org/10.1016/j.jim.2011.05.004.

22. Dinarello, C.A. Biologic basis for interleukin-1 in disease. Blood 1996, 87, 2095-2147.

23. Cartmell, T.; Mitchell, D.; Lamond, F.J.D.; Laburn, H.P. Route of Administration Differentially Affects Fevers Induced by Gram-Negative and Gram-Positive Pyrogens in Rabbits. Experimental Physiology 2002, 87, 391-399, https://doi.org/10.1113/eph8702298.

24. Santos, B.M.; Francescato, H.D.C.; Turcato, F.C.; Antunes-Rodrigues, J.; Coimbra, T.M.; Branco, L.G.S. Increased hypothalamic hydrogen sulphide contributes to endotoxin tolerance by down-modulating PGE2 production. Acta Physiologica 2020, 228, https://doi.org/10.1111/apha.13373.

25. McDonough, W.; Rich, J.; Aragon, I.V.; Abou Saleh, L.; Boyd, A.; Richter, A.; Koloteva, A.; Richter, W. Inhibition of type 4 cAMP-phosphodiesterases (PDE4s) in mice induces hypothermia via effects on behavioral and central autonomous thermoregulation. Biochemical Pharmacology 2020, 180, https://doi.org/10.1016/j.bcp.2020.114158.

26. Siegert, R.; Philipp-Dormston, W.K.; Radsak, K.; Menzel, H. Mechanism of fever induction in rabbits. Infection and Immunity 1976, 14, 1130-1137, https://doi.org/10.1128/iai.14.5.1130-1137.1976.

27. Shibata, M.; Uno, T.; Riedel, W.; Nishimaki, M.; Watanabe, K. Transiently enhanced LPS-induced fever following hyperthermic stress in rabbits. International Journal of Biometeorology 2005, 50, 67-74, https://doi.org/10.1007/s00484-005-0272-4.

28. Stitt, J.T. A study of the variability in the febrile responses of rabbits to endogenous pyrogen. Journal of Applied Physiology 1985, 59, 1254-1257, https://doi.org/10.1152/jappl.1985.59.4.1254. 
29. Gerros, T.C.; Semrad, S.D.; Proctor, R.A. Alterations in clinical, hematological and metabolic variables in bovine neonatal endotoxemia. Can J Vet Res 1995, 59, 34-39.

30. Peñailillo, A.K.; Sepulveda, M.A.; Palma, C.J.; Espinoza, A.; Aguilera, M.; Burgos, R.A.; Carretta, D.; Islas, A.; Pérez, R. Haematological and blood biochemical changes induced by the administration of low doses of Escherichia coli lipopolysaccharide in rabbits. Archivos de medicina veterinaria 2016, 48, 315-320, https://doi.org/10.4067/S0301-732X2016000300012.

31. Nagaraja, T.G.; Bartley, E.E.; Anthony, H.D.; Leipold, H.W.; Fina, L.R. Endotoxin Shock in Calves from Intravenous Injection of Rumen Bacterial Endotoxin. Journal of Animal Science 1979, 49, 567-582, https://doi.org/10.2527/jas1979.492567x.

32. Elmas, M.; Yazar, E.; Uney, K.; Karabacak, A. Pharmacokinetics of Flunixin after Intravenous Administration in Healthy and Endotoxaemic Rabbits. Veterinary Research Communications 2006, 30, 7381, https://doi.org/10.1007/s11259-005-3227-7.

33. Borissov, I.; Andonova, M.J.R.D.M.V. Escherichia coli lipopolysaccharide - induced experimental infection in piglets : clinical and laboratory findings.Rev. Med. Vet 2000, 151, 931-936.

34. Fagiani, F.; Catanzaro, M.; Buoso, E.; Basagni, F.; Di Marino, D.; Raniolo, S.; Amadio, M.; Frost, E.H.; Corsini, E.; Racchi, M.; Fulop, T.; Govoni, S.; Rosini, M.; Lanni, C. Targeting Cytokine Release Through the Differential Modulation of Nrf2 and NF-кB Pathways by Electrophilic/Non-Electrophilic Compounds. Frontiers in Pharmacology 2020, 11, https://doi.org/10.3389/fphar.2020.01256.

35. Grassin-Delyle, S.; Abrial, C.; Salvator, H.; Brollo, M.; Naline, E.; Devillier, P. The Role of Toll-Like Receptors in the Production of Cytokines by Human Lung Macrophages. Journal of Innate Immunity 2020, 12, 63-73, https://doi.org/10.1159/000494463.

36. Mahmood, A.A.; Jabar, A.D.; Maleek, M.I. The Effects of Purified Staphylococcal Enterotoxin A on Gene Expression of Nuclear Factor Kappa B (NF-KB) in Rabbits. Eur. j. mol. clin. Med 2020, 7, 4319-4324.

37. Zhou, M.-L.; Shi, J.-X.; Hang, C.-H.; Cheng, H.-L.; Qi, X.-P.; Mao, L.; Chen, K.-F.; Yin, H.-X. Potential Contribution of Nuclear Factor- $\kappa \mathrm{B}$ to Cerebral Vasospasm after Experimental Subarachnoid Hemorrhage in Rabbits. Journal of Cerebral Blood Flow \& Metabolism 2007, 27, 1583-1592, https://doi.org/10.1038/sj.jcbfm.9600456.

38. Clinton, S.K.; Fleet, J.C.; Loppnow, H.; Salomon, R.N.; Clark, B.D.; Cannon, J.G.; Shaw, A.R.; Dinarello, C.A.; Libby, P. Interleukin-1 gene expression in rabbit vascular tissue in vivo. Am J Pathol 1991, 138, 10051014.

39. Morimoto, N.; Kono, T.; Sakai, M.; Hikima, J.-I. Inflammasomes in Teleosts: Structures and Mechanisms That Induce Pyroptosis during Bacterial Infection. International Journal of Molecular Sciences 2021, 22, https://doi.org/10.3390/ijms22094389.

40. Wakabayashi, G.; Cannon, J.G.; Gelfand, J.A.; Clark, B.D.; Aiura, K.; Burke, J.F.; Wolff, S.M.; Dinarello, C.A. Altered interleukin-1 and tumor necrosis factor production and secretion during pyrogenic tolerance to LPS in rabbits. American Journal of Physiology-Regulatory, Integrative and Comparative Physiology 1994, 267, R329-R336, https://doi.org/10.1152/ajpregu.1994.267.1.R329.

41. Kaplan, E.; Dinarello, C.A.; Wakabayashi, G.; Burke, J.F.; Connolly, R.S.; Gelfand, J.A. Interleukin-1 pretreatment protects against endotoxin-induced hypotension in rabbits: association with decreased tumor necrosis factor levels. J. Infect. Dis 1993, 167, 244-247.

42. Benoot, T.; Piccioni, E.; De Ridder, K.; Goyvaerts, C. TNF $\alpha$ and Immune Checkpoint Inhibition: Friend or Foe for Lung Cancer? International Journal of Molecular Sciences 2021, 22, https://doi.org/10.3390/ijms22168691.

43. Weber, M.A.; Schnyder-Candrian, S.; Schnyder, B.; Quesniaux, V.; Poli, V.; Stewart, C.L.; Ryffel, B. Endogenous leukemia inhibitory factor attenuates endotoxin response. Laboratory investigation; a journal of technical methods and pathology 2005, 85, 276-284.

44. Floris, I.; Rose, T.; Rojas, J.A.C.; Appel, K.; Roesch, C.; Lejeune, B. Pro-Inflammatory Cytokines at UltraLow Dose Exert Anti-Inflammatory Effect In Vitro: A Possible Mode of Action Involving Sub-Micron Particles? Dose-Response 2020, 18, 1-11, https://doi.org/10.1177/1559325820961723.

45. Ledeboer, A.; Binnekade, R.; Brevé, J.J.P.; Bol, J.G.J.M.; Tilders, F.J.H.; Van Dam, A.-M. Site-specific modulation of LPS-induced fever and interleukin-1 $\beta$ expression in rats by interleukin-10. American Journal of Physiology-Regulatory, Integrative and Comparative Physiology 2002, 282, R1762-R1772, https://doi.org/10.1152/ajpregu.00766.2001.

46. Seemann, S.; Zohles, F.; Lupp, A. Comprehensive comparison of three different animal models for systemic inflammation. Journal of Biomedical Science 2017, 24, 1-17, https://doi.org/10.1186/s12929-017-0370-8.

47. Raetzsch, C.F.; Brooks, N.L.; Alderman, J.M.; Moore, K.S.; Hosick, P.A.; Klebanov, S.; Akira, S.; Bear, J.E.; Baldwin, A.S.; Mackman, N.; Combs, T.P. Lipopolysaccharide inhibition of glucose production through the Toll-like receptor-4, myeloid differentiation factor 88, and nuclear factor $\mathrm{kb}$ pathway. Hepatology 2009, 50, 592-600, https://doi.org/10.1002/hep.22999. 